NBER WORKING PAPER SERIES

SOCIAL SECURITY PROGRAMS AND EMPLOYMENT AT OLDER AGES IN THE NETHERLANDS

\author{
Klaas de Vos \\ Arie Kapteyn \\ Adriaan Kalwij \\ Working Paper 25250 \\ http://www.nber.org/papers/w25250 \\ NATIONAL BUREAU OF ECONOMIC RESEARCH \\ 1050 Massachusetts Avenue \\ Cambridge, MA 02138 \\ November 2018
}

The views expressed herein are those of the authors and do not necessarily reflect the views of the National Bureau of Economic Research.

NBER working papers are circulated for discussion and comment purposes. They have not been peer-reviewed or been subject to the review by the NBER Board of Directors that accompanies official NBER publications.

(C) 2018 by Klaas de Vos, Arie Kapteyn, and Adriaan Kalwij. All rights reserved. Short sections of text, not to exceed two paragraphs, may be quoted without explicit permission provided that full credit, including (C) notice, is given to the source. 
Social Security Programs and Employment at Older Ages in the Netherlands

Klaas de Vos, Arie Kapteyn, and Adriaan Kalwij

NBER Working Paper No. 25250

November 2018

JEL No. H55,J08,J26

\section{ABSTRACT}

There have been a vast number of social security reforms aimed at increasing employment at older ages over the last two decades in the Netherlands. These reforms mainly lead to more stringent eligibility criteria for, and reduced generosity of, social security programs. Our empirical evidence suggests that these reforms are likely to have contributed to individuals working longer, but it is difficult to pinpoint which reforms have been most effective. Furthermore, we show that the recent increase in the state pension eligibility age is likely to further increase employment at older ages.

Klaas de Vos

CentERdata

Tilburg University

Warandelaan 2

5037 AB Tilburg

The Netherlands

K.deVos@uvt.nl

Arie Kapteyn

University of Southern California

Center for Economic and Social Research

635 Downey Way Suite 312

Los Angeles, CA 90089-3332

and NBER

kapteyn@usc.edu

\author{
Adriaan Kalwij \\ Utrecht University School of Economics \\ Network for Studies on Pensions, Aging \\ and Retirement \\ The Netherlands \\ a.s.kalwij@uu.nl
}




\title{
Social security programs and employment at older ages in the Netherlands
}

Klaas de Vos, Arie Kapteyn and Adriaan Kalwij

February 19, 2018

\begin{abstract}
There have been a vast number of social security reforms aimed at increasing employment at older ages over the last two decades in the Netherlands. These reforms mainly lead to more stringent eligibility criteria for, and reduced generosity of, social security programs. Our empirical evidence suggests that these reforms are likely to have contributed to individuals working longer, but it is difficult to pinpoint which reforms have been most effective. Furthermore, we show that the recent increase in the state pension eligibility age is likely to further increase employment at older ages.
\end{abstract}

\section{Introduction}

The rising labor force participation at older ages since the mid-nineteen-nineties in the Netherlands has been attributed to, among other factors, older workers’ improved health, increased levels of education and better matched skills with labor demand, changes in social security programs ${ }^{1}$ such as disability insurance, unemployment insurance and early retirement schemes (Kalwij, Kapteyn, \& de Vos, 2017). Kapteyn and de Vos (1999) have

\footnotetext{
${ }^{1}$ Social security programs (SSPs) encompass state pension (SP), disability insurance (DI), unemployment insurance (UI), social assistance (SA) and other public transfer programs available at older ages, such as tax exemptions for early retirement (ER) pensions until 2006 and private pensions from the state pension age (SPA) onwards.
} 
investigated the role of financial incentives induced by early retirement schemes in the decline in labor force participation during the 1980s and early 1990s in the Netherlands. This chapter expands on this study by examining the eligibility criteria and the generosity of the different social security programs from 1980 until 2016, and the changes during this period in the implicit tax rates on working longer at older ages induced by these programs. In addition, our chapter examines the importance of the state pension age (SPA) for working longer.

The outline of this chapter is as follows. Section 2 discusses institutional changes in social security over the last decades. Section 3 presents for each of the most pertinent social security programs (SSPs) the implicit tax rates on working longer conditional on being eligible for it. Next, Section 4 presents employment and SSPs’ participation rates. Graphical evidence is provided using a cohort perspective on how the labor force participation at older ages might have been affected by the introduction and reforms of SSPs. In addition, empirical evidence is presented on the effect of recent changes in the statutory state pension age (SPA) on working longer. Section 6 concludes.

\section{Description of Institutional Changes}

Table 1 provides an overview of the most important reforms over the last decades of the State Pension (SP), Unemployment Insurance (UI), Disability Insurance (DI), Early Retirement (ER), and Private/Occupational Pension (PP) schemes.

UI, DI and ER are available for workers before the State Pension age. After the State Pension age (SPA), individuals can no longer receive benefits from these schemes and receive a flat rate public pension benefit. Hence, after the SPA, all individuals are covered by the SP scheme. The PP schemes often have two regimes: providing early retirement pensions before the SPA and providing private pensions after the SPA. The pensions to be received may vary, 
dependent on the PP/ER schemes in which the worker is enrolled. These PP/ER schemes can be occupation, firm or sector specific.

\section{State Pension (SP)}

The flat rate State Pension (SP) is financed by pay as you go social insurance contributions. By and large, since 1974, the flat rate state pension is indexed by the after tax minimum wage. Revisions have included the introduction of an independent pension entitlement for married women in $1985^{2}$, and an entitlement to supplementary State Pension benefits for persons with a spouse younger than 65 (1985; revised 1994; abolished in 2015). As from 2013, the State Pension age, which had been 65 from the start, is increasing gradually. The State Pension age will reach 67 in 2021. After 2021, it will increase further following the average increase in life expectancy.

\section{Early retirement $(\mathrm{ER})$}

ER was introduced in most sectors of the economy during the 1970s. In most cases it entailed an offer too good to refuse at least until the end of the 1990s. The ER benefit usually amounted to $80 \%$ of previous earnings without actuarial adjustment for later take-up. It lasted until the State Pension age, when State Pension and occupational/private pensions kicked in. The prospect of exploding costs once the large baby boom cohorts started to reach the ER age led to reforms by the end of the 1990s. In most cases a reduction of the ER benefit was combined with the introduction of more or less actuarially fair adjustments for the age at which one would take early retirement. As a result, the employee could still opt for retiring early, but with a reduced pension. By 2006, the government terminated the tax exemption for ER contributions that would enable a retirement age lower than 65. Only systems offering a

\footnotetext{
${ }^{2}$ Before 1985, only the husband in a married couple was entitled to the State Pension.
} 
replacement rate of at most $70 \%$ of previous earnings at the State Pension age of 65, and actuarially fair reductions for early claiming could still collect tax exempt contributions.

\section{Occupational/private pensions (PP)}

In addition to the State Pension, most employees accumulate fully funded occupational pension rights and supplement their State Pension to (ideally) 70\% of previous earnings. Participation in PP schemes is mostly mandatory. Pension funds, operating by sector, and, in a number of cases, by firm, invest the pension contributions, which are usually shared by the employer and employee. Since the early 2000s, pension funds have started to reduce the generosity of occupational pensions by shifting from benefits based on final earnings to benefits based on average earnings. Moreover, in general the indexation of benefits, which used to be based on the wage index, has become less generous following successive stock market downturns, affecting the investment returns of pension funds. Some pension funds had to reduce the pension benefits in nominal terms (Kalwij, Alessie, Gardner \& Ali, 2018).

\section{Disability Insurance (DI)}

Introduced in 1967, the Dutch Disability Insurance aimed to insure employees against loss of earnings as a result of long-term illness or incapacity. If after one year of illness the employee could not resume work, he/she would be entitled to an earnings-related DI benefit that could last until the State Pension age.

Starting in the 1970s, the number of individuals on DI showed a steady increase until the 1990s, much more than expected when the DI legislation was introduced and much more than could be expected given the average health status of the population. In fact, with unemployment rising fast in the mid-1970s, the route to DI was generally used by employers and employees as an alternative to unemployment. As a result, expenditures on DI soared. Since the start of the 1980s government policy has sought to reverse this trend by various 
reforms to limit access to DI, increase outflow out of DI and by lowering the average DI benefit. In 1985, the replacement rate of DI was lowered from $80 \%$ to $70 \%$. In 1987 , access to the full DI was limited for partially disabled unemployed new entrants. In the early 1990s the duration of the full DI benefit was limited for new entrants younger than 50, stricter disability criteria were introduced for entry into DI and younger DI recipients were to be retested. Still, mainly because most employees took out private insurance to compensate for the shorter duration, DI remained an attractive option.

Next to limiting the access and the generosity of the benefit, policies were also introduced to shift the costs to firms with high numbers of employees exiting to DI. First, the costs of sickness benefits were charged directly to the employer for two to six weeks (1994), and later on for a full year preceding the exit to DI, and, second, in 1998, for large firms experience rating was introduced. All these reforms did not succeed in substantially reducing the numbers of DI recipients, however. As a result, as from 2002, employers and employees were made jointly responsible for taking sufficient action for reintegration into the workforce during the year of sickness preceding exit to DI. Moreover, this sickness period could be extended if insufficient reintegration measures had been taken. As of 2004, exit to DI only happened after two years of sickness, during which time the employer paid sickness benefits. As of 2006, a new DI law made a strict distinction between fully and permanently disabled and partially or temporarily disabled workers. The former group was to receive a generous 75\% of their previous earnings until the State Pension age. The latter group would receive a less generous benefit depending on previous earnings, the number of weeks worked before, and the current earnings (if any) and the percentage of previous earnings that the employee was deemed to be capable of earning. Furthermore, once again a retest operation was set up for existing DI beneficiaries younger than 50 . 


\section{Unemployment Insurance (UI)}

For workers approaching 60 who were not entitled to ER and who could not plausibly retire via DI, Unemployment Insurance (UI) offered a third pathway out of the labor force before the State Pension age. In most cases, it offered a replacement rate of 70\%, and furthermore, no obligation existed to search for employment after the age of 57.5. As of 2004, persons aged 57.5 or older receiving UI are no longer exempt from the requirement to seek work. In other words, they are no longer 'automatically' receiving UI until the State Pension age but have to try to find work and accept a job offer. Moreover, as of October 1, 2006, the maximum duration of UI is 38 months. After that period all that is left is a means tested entitlement to Social Assistance (SA) with a benefit equal to the after tax minimum wage. 
Table 1: Timeline reforms to State Pension (SP), Disability Insurance (DI), Unemployment Insurance (UI), and Early Retirement (ER) and Occupational Pension (PP)

\begin{tabular}{|c|c|c|c|c|}
\hline & SP (flat rate, age 65) & ER, PP & $\begin{array}{l}\text { DI / (long-term) Sickness } \\
\text { Insurance }\end{array}$ & UI \\
\hline $\begin{array}{l}\text { Until } \\
1980\end{array}$ & $\begin{array}{l}\text { 1957: State pension replaces earlier } \\
\text { emergency benefit } \\
\text { 1974: Benefit raised and linked to } \\
\text { net minimum wage }\end{array}$ & $\begin{array}{l}\text { 1975-1982: Gradual introduction of } \\
\text { ER by sector/firm/department; }\end{array}$ & $\begin{array}{l}\text { 1967: Introduction of DI } \\
\text { (20,000 beneficiaries expected) }\end{array}$ & 1949: Introduction of UI \\
\hline 1980 & & ER contribution tax deductible & & \\
\hline 1985 & $\begin{array}{l}\text { Married women get independent } \\
\text { claim } \\
\text { Earnings tested supplement when } \\
\text { partner is younger than } 65\end{array}$ & & $\begin{array}{l}764,000 \text { beneficiaries, replacement } \\
\text { rate reduced from } 80 \text { to } 70 \%\end{array}$ & $\begin{array}{l}\text { UI: Replacement rate reduced to } \\
70 \%\end{array}$ \\
\hline 1987 & $\begin{array}{l}\text { SP: Distinction between married and } \\
\text { cohabiting couples abolished } \\
\text { SP: Introduction single parent } \\
\text { allowance }\end{array}$ & & $\begin{array}{l}\text { No more (full) DI for (partially) } \\
\text { unemployed }\end{array}$ & $\begin{array}{l}\text { UI: Changes in eligibility and } \\
\text { benefit period } \\
\text { Earnings related benefit followed by } \\
\text { continuation benefit }\end{array}$ \\
\hline 1991 & & & & UI: Eligibility revised \\
\hline 1993 & & & $\begin{array}{l}\text { (i) Persons younger than } 50 \text { receive } \\
\text { DI for a limited period } \\
\text { (ii) Stricter disability criteria. } \\
\text { (iii) Retesting of younger DI } \\
\text { recipients }\end{array}$ & \\
\hline 1994 & $\begin{array}{l}\text { SP: Earnings tested partner } \\
\text { supplement adapted }\end{array}$ & & $\begin{array}{l}\text { Introducing employer paid periods } \\
\text { of sickness (2-6 weeks) }\end{array}$ & \\
\hline 1995 & & & & $\begin{array}{l}\text { UI: Eligibility revised, introduction } \\
\text { short term benefit }\end{array}$ \\
\hline 1996 & & & $\begin{array}{l}\text { (i) Sickness benefit privatized: } \\
\text { employer pays } 70 \% \text { of earnings ( } 1 \\
\text { yr) } \\
\text { (ii) Exemptions for earnings tested } \\
\text { supplement abolished }\end{array}$ & \\
\hline 1998 & & & $\begin{array}{l}\text { (i) Introduction of (limited) } \\
\text { experience rating DI contributions }\end{array}$ & \\
\hline
\end{tabular}




\begin{tabular}{|c|c|c|c|c|}
\hline & & & $\begin{array}{l}\text { employer. } \\
\text { (ii) Public employees included in DI }\end{array}$ & \\
\hline $\begin{array}{l}2000- \\
05\end{array}$ & & $\begin{array}{l}\text { ER/PP: Trend towards actuarially } \\
\text { fairer flexible ER age including } \\
\text { options for partial retirement; } \\
\text { Entitlement based on average wage } \\
\text { instead of final wage }\end{array}$ & & \\
\hline 2001 & & & & UI: Public employees included \\
\hline 2002 & & & $\begin{array}{l}\text { Stricter reintegration rules in case of } \\
\text { sickness }\end{array}$ & \\
\hline 2003 & & & $\begin{array}{l}\text { Experience rating for small } \\
\text { employers abolished }\end{array}$ & UI: Abolition of continuation benefit \\
\hline 2004 & & & $\begin{array}{l}\text { (i) Sickness benefit period extended } \\
\text { to } 2 \text { years } \\
\text { (ii) Strict reevaluation DI recipients } \\
\text { younger than } 50\end{array}$ & $\begin{array}{l}\text { UI: Persons aged } 57.5+\text { have to } \\
\text { apply for jobs }\end{array}$ \\
\hline 2006 & & $\begin{array}{l}\text { ER: Fiscal friendly treatment of ER } \\
\text { contributions repealed }\end{array}$ & $\begin{array}{l}\text { Introduction of new DI: strict } \\
\text { distinction between partially and } \\
\text { fully, permanently disabled }\end{array}$ & $\begin{array}{l}\text { UI: benefit period shortened, higher } \\
\text { benefit first two months }\end{array}$ \\
\hline 2008 & & & Experience rating DI abolished & \\
\hline 2013 & & & & $\begin{array}{l}\text { UI: Employment period calculation } \\
\text { revised }\end{array}$ \\
\hline 2013- & SP: Gradual increase in SP age & & & \\
\hline 2015- & Partner $<65$ supplement abolished & & & \\
\hline 2016- & & & & $\begin{array}{l}\text { UI: Gradual shortening of benefit } \\
\text { period }\end{array}$ \\
\hline
\end{tabular}

Main Source: Kroniek van de sociale verzekeringen 2008, www.uwv.nl 


\section{Stylized implicit tax rates}

For workers eligible for one or more retirement pathways, some of the reforms discussed in the previous section heavily affect the financial incentives to retire. Other reforms only affect eligibility, whilst, given eligibility, financial incentives are hardly affected. One convenient incentive measure that adequately summarizes the monetary effect of retiring now, compared to postponing it one more year is the implicit tax rate on work, defined as the difference between the discounted future benefits when retiring now or one year later, divided by the yearly earnings. ${ }^{3}$ A positive implicit tax rate is an incentive to retire now and a negative implicit tax rate is an incentive to postpone retirement.

Figures 1 through 4 present stylized implicit tax rates for average-waged workers eligible for respectively DI, UI, ER/PP and SP, for selected years between 1980 and 2015. All tax rates are conditional on eligibility. As mentioned above, various reforms have been attempted to limit the number of workers eligible for DI, of which the most recent appears to have been the most successful. Figure 1 shows that for those eligible, the incentives have not changed very much between 1980 and 2006. With an implicit tax rate on continued work of 80 to $90 \%$, the financial incentive to retire via the DI channel remains strong. In other words, once eligible, the implicit tax rate suggests that retiring via the DI pathway is a financially attractive proposition.

From figure 2 we can infer that from 1987 to 2004, the implicit tax rate on postponing retirement via the UI pathway was also positive, at least for persons aged 58 and over. However, the tax rates are clearly lower than for the DI pathway.

\footnotetext{
${ }^{3}$ Notably, the stylized implicit tax rates presented in this paper divide the difference between future discounted after tax benefits (net Social Security Wealth) when retiring now and one year later by annual after tax earnings. The pay-roll taxes on earnings incurred when retiring one year later are not deducted from the future benefits.
} 
Figure 3 suggests that for workers eligible for Early Retirement at age 60, until recently, postponing retirement from age 59 until age 60 would have been a very smart decision from a financial standpoint, because the potential retiree would lose all entitlements to Early Retirement benefits if he or she would retire earlier. On the other hand, postponing retirement after age 60 was not very attractive, because there used to be hardly any actuarial compensation for retiring later than the earliest possible retirement age. Only recently, an actuarially fair compensation is being offered for postponing retirement. As a result, this no longer has a negative impact on social security wealth (SSW). In addition, the negative tax rate on postponing retirement from age 59 to age 60 has as well disappeared since eligibility for early retirement no longer depends on being employed. Notably, while some large pension funds offered Early Retirement as of age 60, others had an ERA of 61 or 62, and Figure 3 would shift accordingly.

Figure 4 shows that for persons who are only eligible for the State Pension, SSW is not affected by the retirement date. These workers would receive the same State Pension starting from the statutory State Pension age, no matter at which age they would choose to retire.

It is clear that these incentives differ considerably depending on the pathways a potential retiree is eligible for. Unfortunately, data that allow us to obtain a reliable estimate of the effects of these incentives at the individual level, taking account of the possible eligibility for various pathways, are not available. For the DI pathway, the problem is that eligibility can only be inferred for persons taking up DI. However, not taking up DI does not necessarily imply not being eligible. For many retirees, the ER/SP pathway would be financially more attractive, and by taking this pathway, they would also avoid the possible stigma associated with retiring via DI. In addition, despite the fact that there is a positive tax on working associated with postponing retirement via DI, the net replacement rate is still below $100 \%$. 
The incentives associated with the ER/SP pathway depend on the specific program (pension fund) in which the potential retiree is enrolled. This determines the Early Retirement age, the replacement rate, and the actuarial adjustment (if any), and/or the date at which actuarial adjustment was introduced. The exact conditions also depend on the possible membership of other pension funds in earlier years, as well as on previous earnings.

\section{Figure 1 Implicit tax rates for Disability Insurance (conditional on elgibility)}

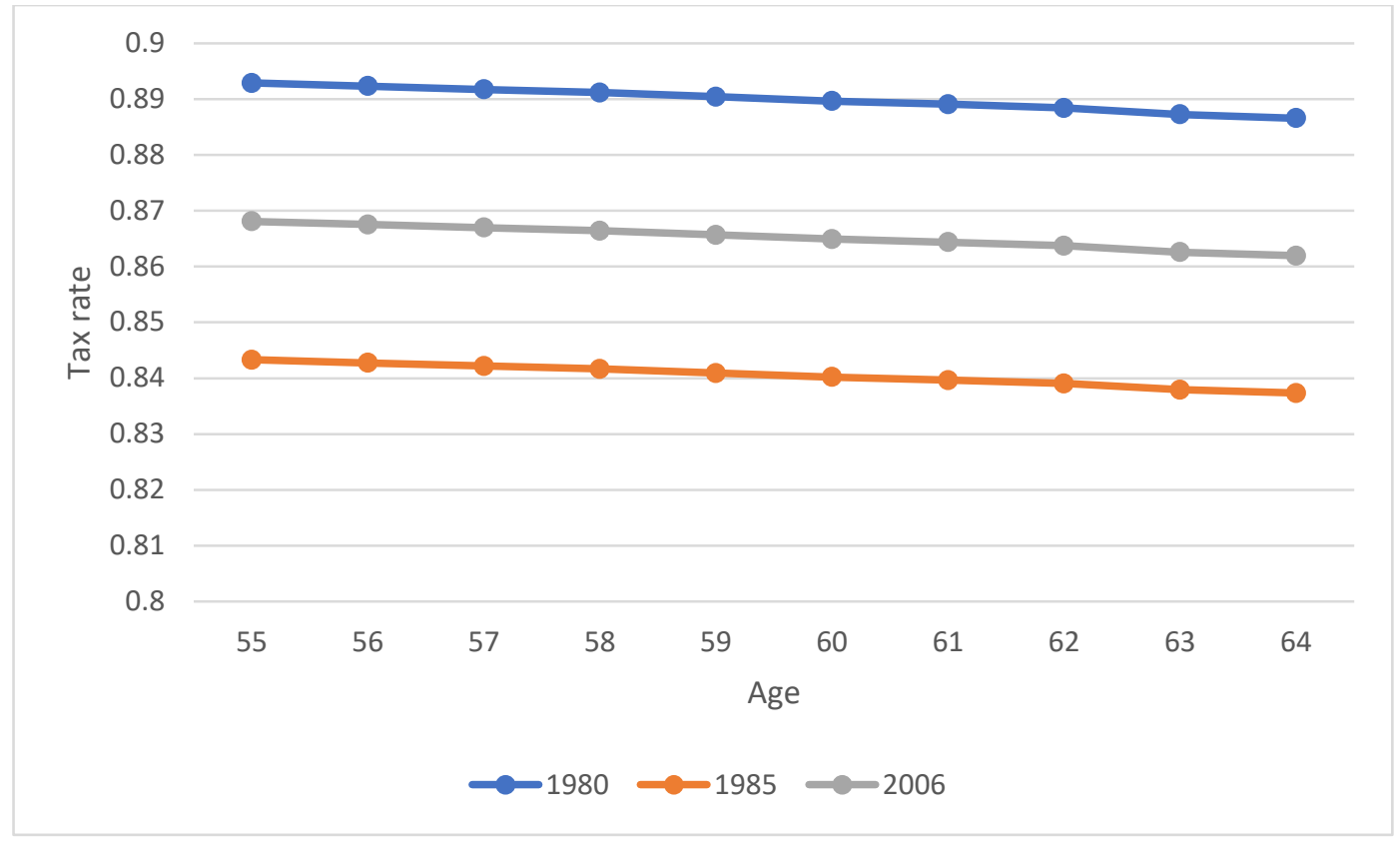

Note: We assume for the 2006 series that the shortening (in 1993) of the duration of income replacement benefits to three years at the ages under 58 and to six years from age 58 onwards is fully insured away. That is, effectively DI recipients receive a $75 \%$ replacement of their income until SPA. 
Figure 2 Implicit tax rates for Unemployment Insurance (conditional on elgibility)

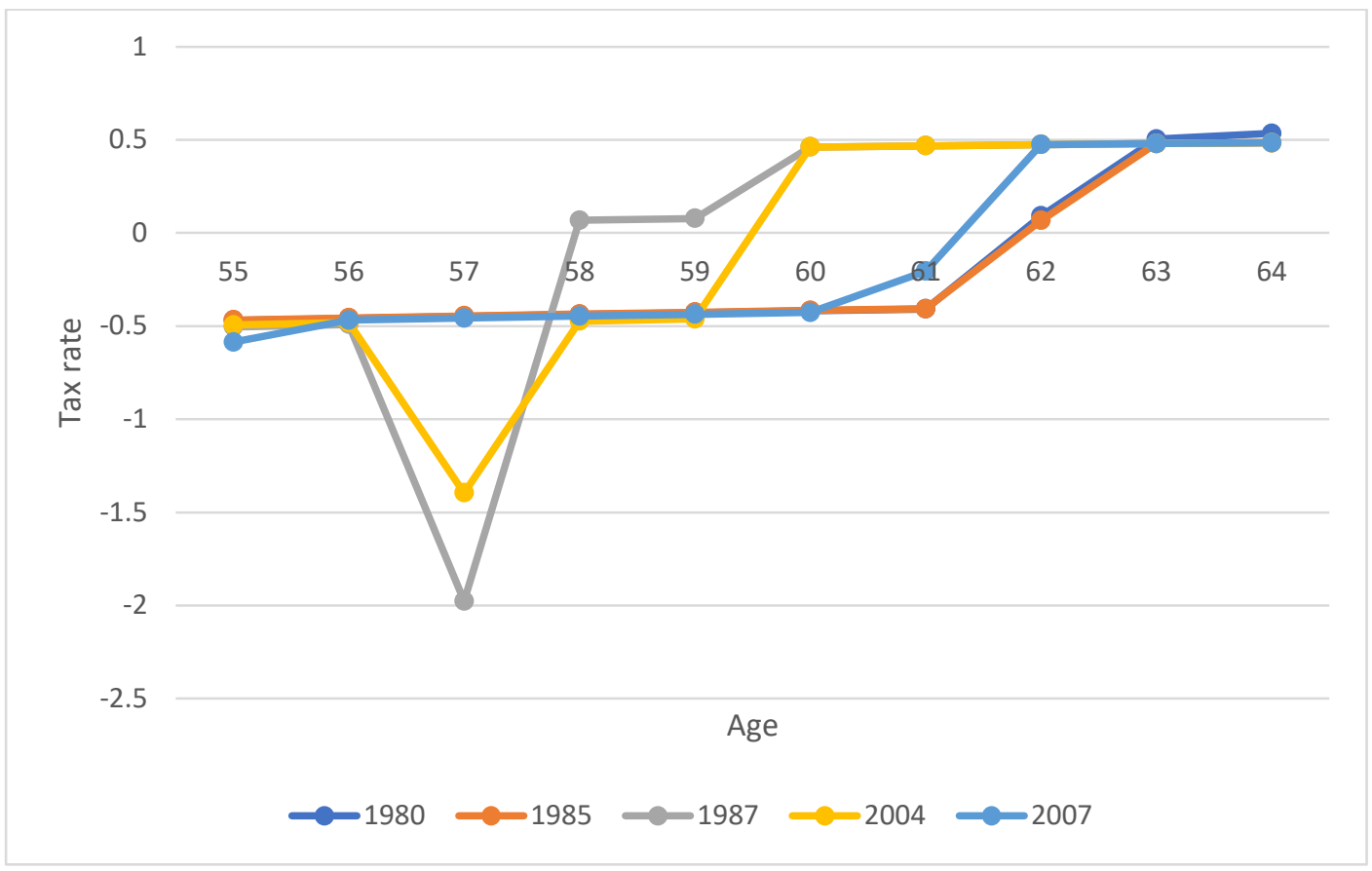

Figure 3 Implicit tax rates for Early Retirement (conditional on elgibility)

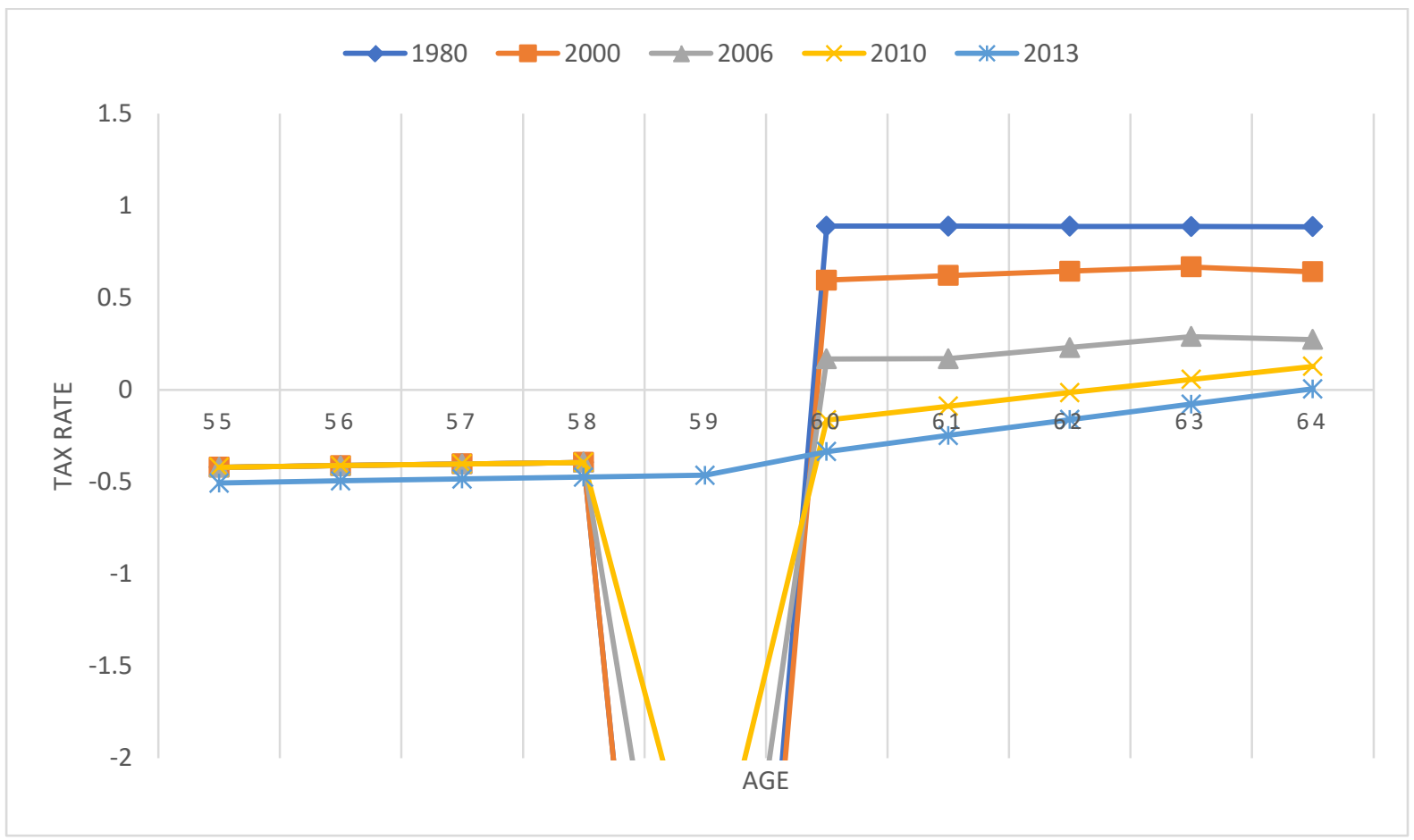

Note: We assume eligibility at age 60 . Eligibility age varies across pension funds and over time within about the age range 58-62. 


\section{Figure $4 \quad$ Implicit tax rates for State Pension (SPA= 65 years)}

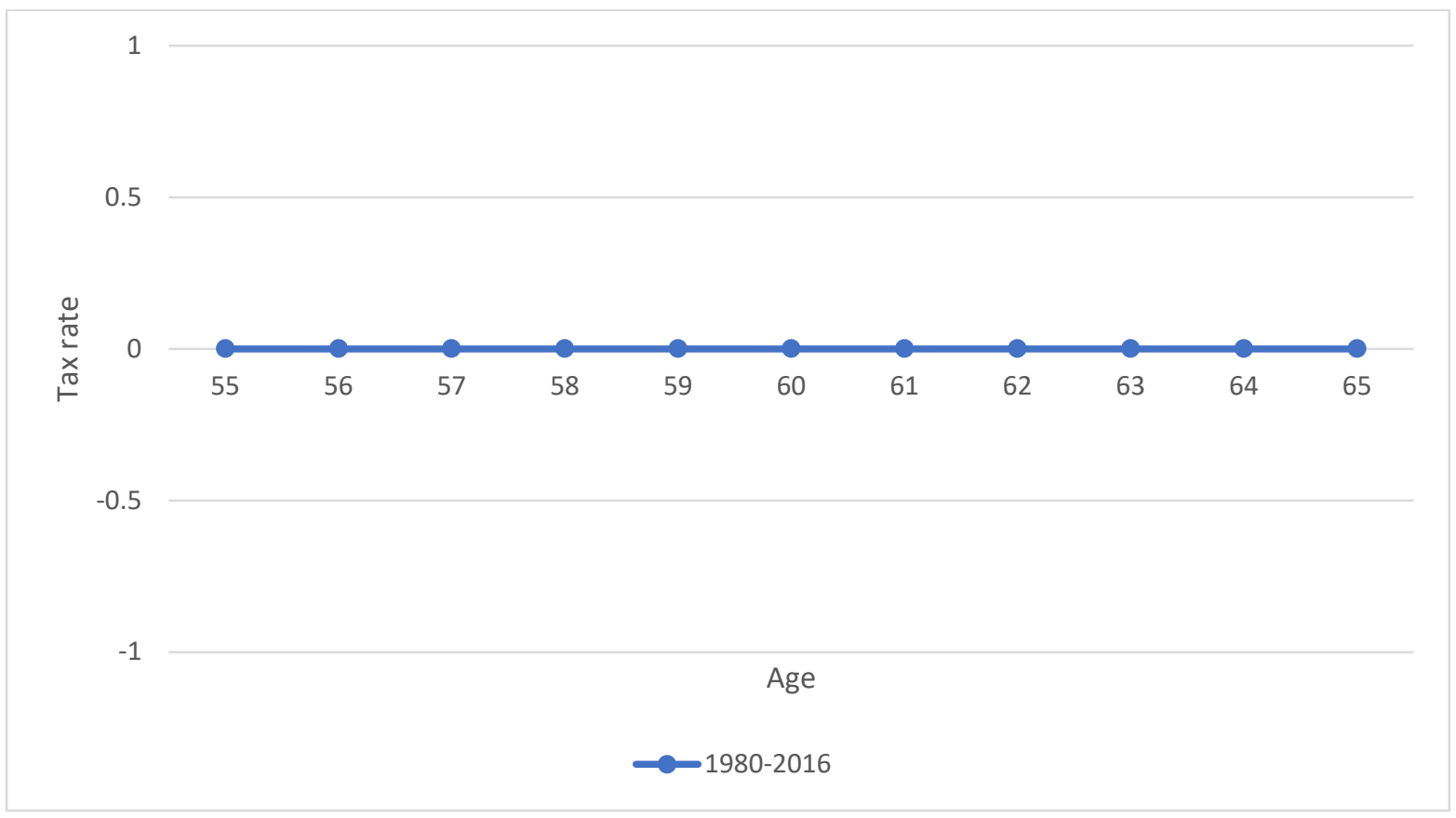

\section{Labor force participation}

The fall in men's employment rates at older ages from the mid-nineteen seventies until the mid-nineteen-nineties in the Netherlands and the rise in employment rates thereafter (see Figure 5) have, in part, been attributed to SSP reforms (Kalwij, Kapteyn, \& de Vos, 2017; and reference therein).

Figure 6 shows men’s unemployment rates, including individuals who receive unemployment insurance benefits and social assistance, from 1975 onwards. Figures 7-8 show men's participation in DI and ER programs from 1975 onwards. DI participation decreased during the nineteen-eighties, possibly due to better health of older workers and increasing participation in early retirement schemes (Figure 7), and perhaps due to some minor DI reforms such as a reduction in the replacement rate from $80 \%$ to $70 \%$ (Table 1). Until the mid-nineteen nineties ER participation increased (Figure 7), most likely due to the implicit 
taxes on continuing work, once eligible (Figure 3). In addition, the sharp rise in ER participation during the first half of the nineteen nineties may also be related to more stringent eligibility criteria for DI and UI (Table 1). Together with rising unemployment rates, employment rates continued to decrease until the mid-nineteen-nineties.

Since the mid-nineteen-nineties there have been a vast number of SSP reforms aimed at individuals working longer, which made it more difficult or less attractive for individuals to go on DI or UI, or retire early (Table 1). Figures 5-8 suggest that these reforms have been effective but it is difficult to pinpoint which reforms have been most effective. 


\section{Figure 5 Men's employment rate}

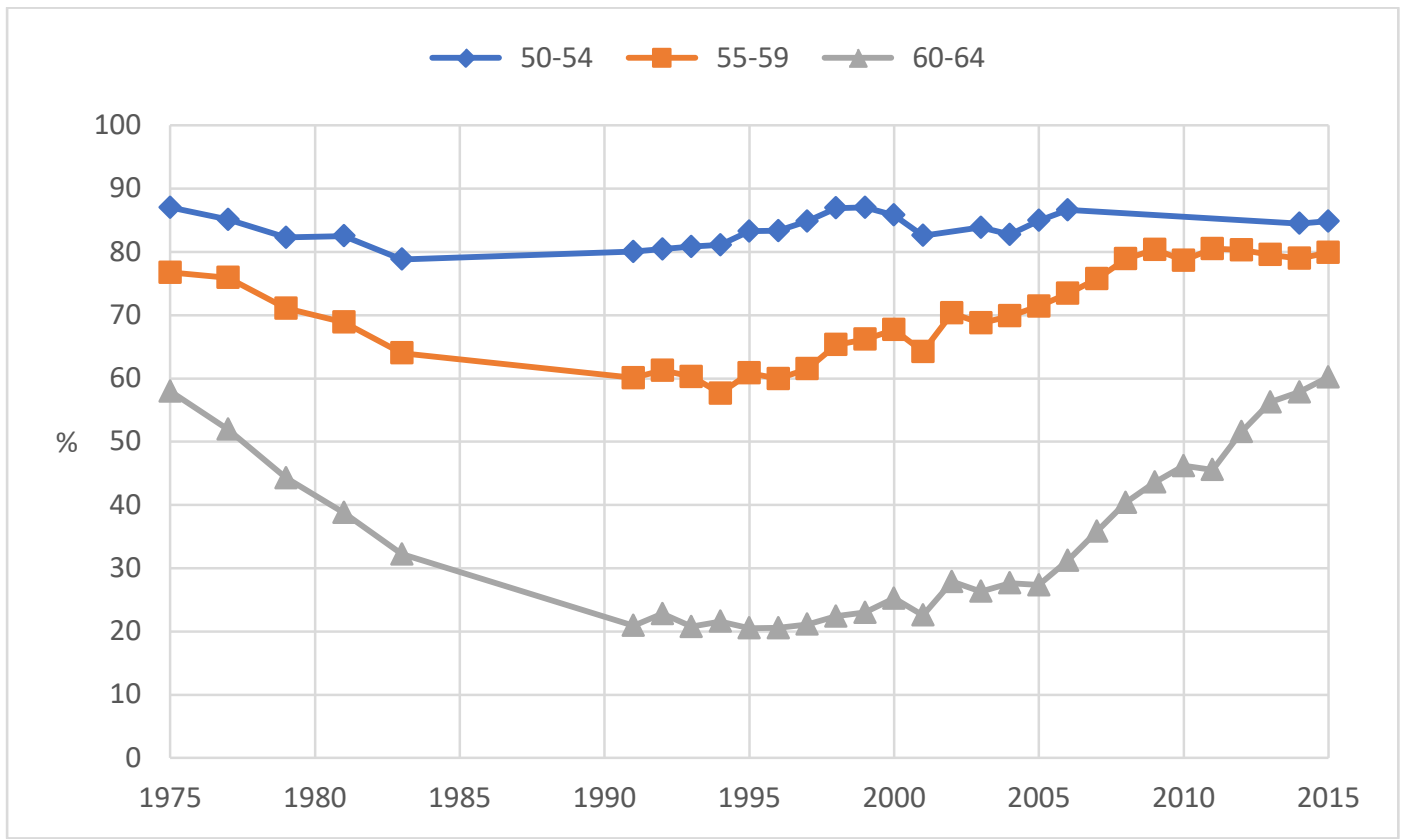

Source: Statistics Netherlands, Labor Force Survey (Enqûete Beroepsbevolking; EBB).

\section{Figure 6 Men's unemployment rate}

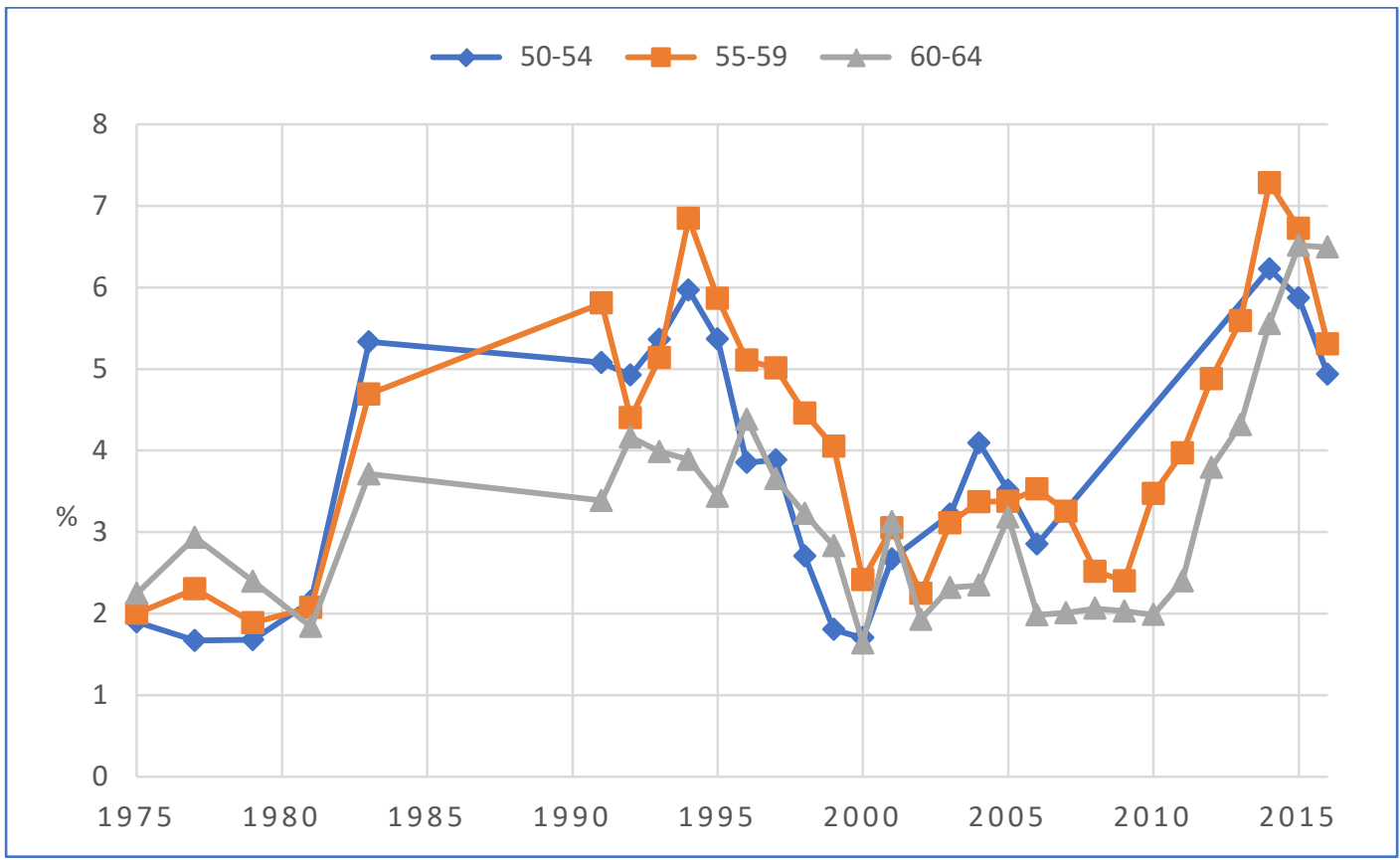

Note: The unemployment rate includes individuals on unemployment insurance and social assistance. Source: Statistics Netherlands, Labor Force Survey (Enqûete Beroepsbevolking; EBB). 
Figure $7 \quad$ Men's early retirement rate

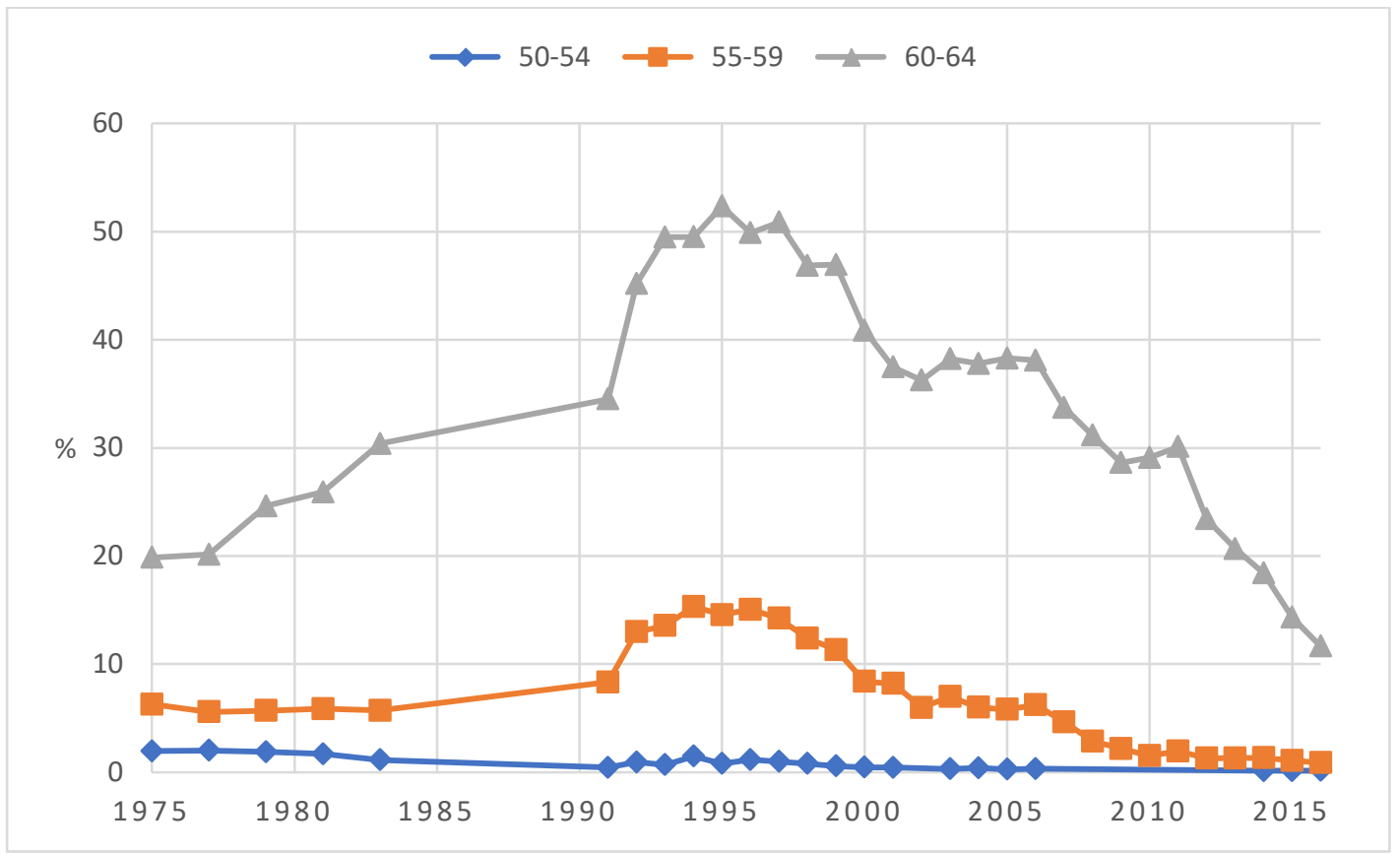

Source: Statistics Netherlands, Labor Force Survey (Enqûete Beroepsbevolking; EBB).

\section{Figure 8 Men's disability insurance rate}

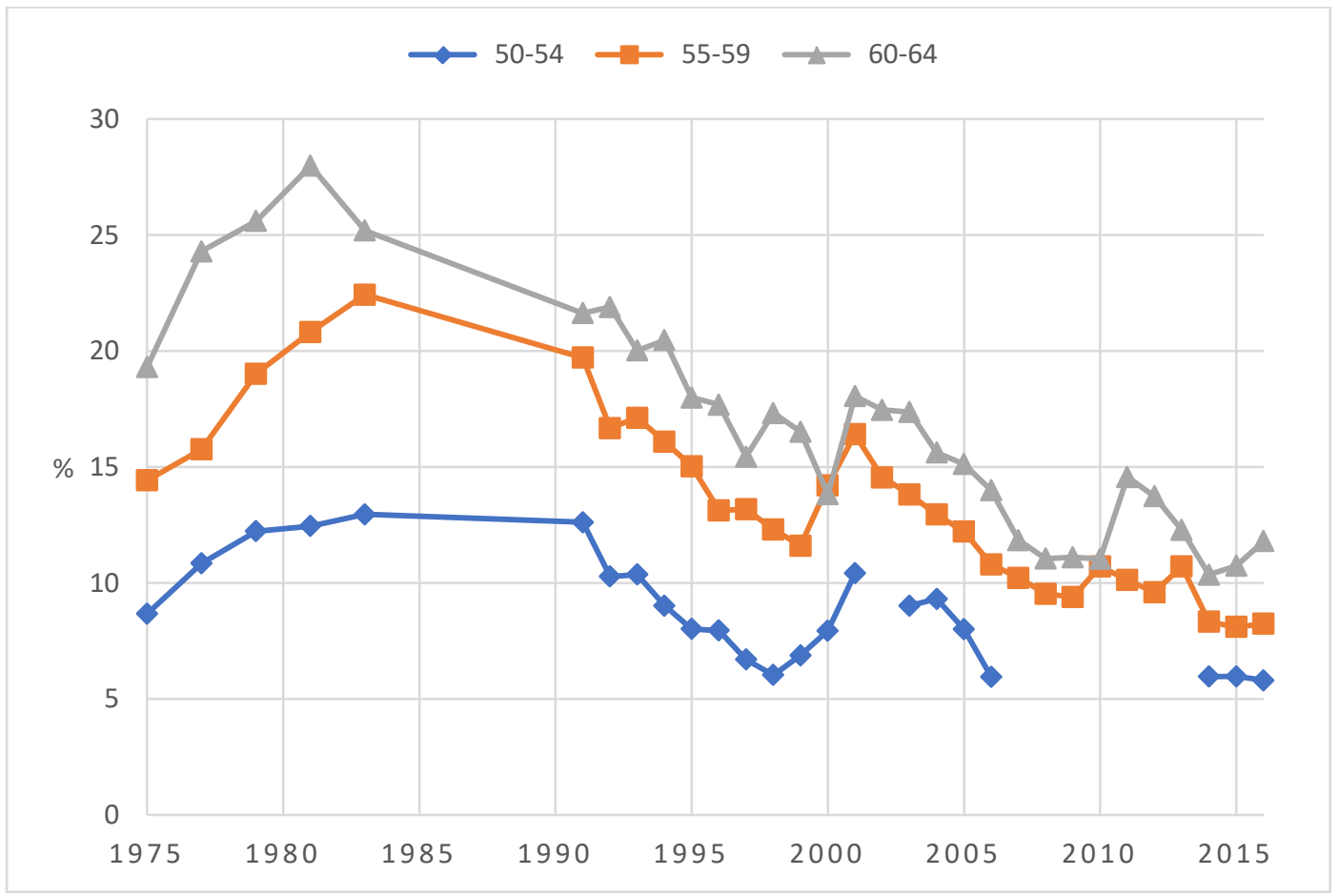

Source: Statistics Netherlands, Labor Force Survey (Enqûete Beroepsbevolking; EBB). 


\subsection{A cohort perspective}

Different cohorts have faced different retirement incentives through the various pathways over their lifetimes. This may have resulted in different age profiles of employment rates across cohorts. Indeed, Figure 9 shows this for the employment rates for men aged 55 to 69 for the cohorts born in 1910, 1915, 1940, 1945, 1950 and 1955. The three generations considered here were or are facing different social security programs over their life course (Table 1). The old (1910 \& 1915 cohorts) faced less generous social security provisions, especially in the years when most SSPs where not yet in place; the young (1950 \& 1955 cohorts) face stricter eligibility rules and less generous benefits than the cohorts in between (the 1940 \& 1945 cohorts). The employment rates in the figure mirror these lifetime differences in SSPs, compared to the young and old generation, the in-between generations who enjoyed a relatively more generous or accessible SSPs over their life course have the lowest employment rates at older ages. If we look at 60 years-old individuals, we see that in 1975, before the introduction of ER, their participation rate was 70\%, whilst in 2000 and 2005 their participation rate was only 40\%. In 2010 and 2015, the participation rate of 60 years-old individuals was back to 70\%. The participation rates for 60 to 63 years old individuals show a similar trajectory. These numbers suggest that the eligibility and generosity of SSPs are important for the decision whether or not to remain employed at older ages.

Figure 10 shows participation rates in the different SSPs for three groups of cohorts. Due to low numbers of observations, cohort years needed to be aggregated. We followed the same approach as above, and only present it for selected cohort-groups that we a priori believe to have faced rather different SSPs over their life courses (in terms of eligibility and generosity). The generation of '40-'44, shows higher rates of ER than the old and young generations (born 
before 1924 or between 1950 and 1954, respectively). This is the generation that faced generous ER incentives at the ages that mattered. Concerning DI participation, we see a higher DI rate for the older generations. This can be a combination of better health and stricter DI eligibility rules for the younger compared to the older generations. Concerning generational differences in unemployment at older ages, Figure 10 shows that the unemployment rate is higher for the generation of '50-'54 than for the other generations.

Figure 9 Cohort specific age profiles (Ages 55-69) of employment rates.

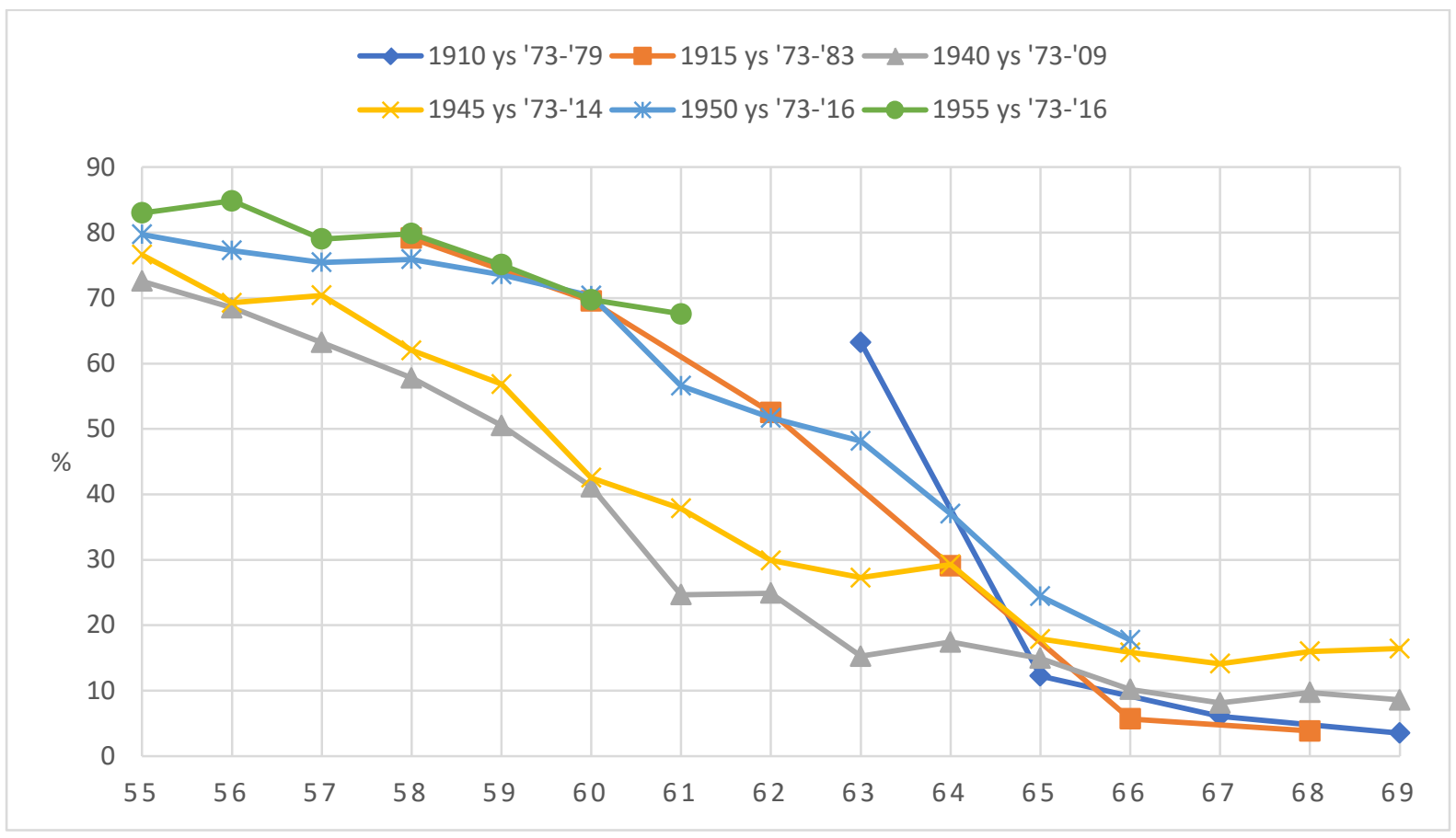

Source: Statistics Netherlands, Labor Force Survey (Enqûete Beroepsbevolking; EBB). 
Figure 10 Cohort differences in DI and ER participation and unemployment.
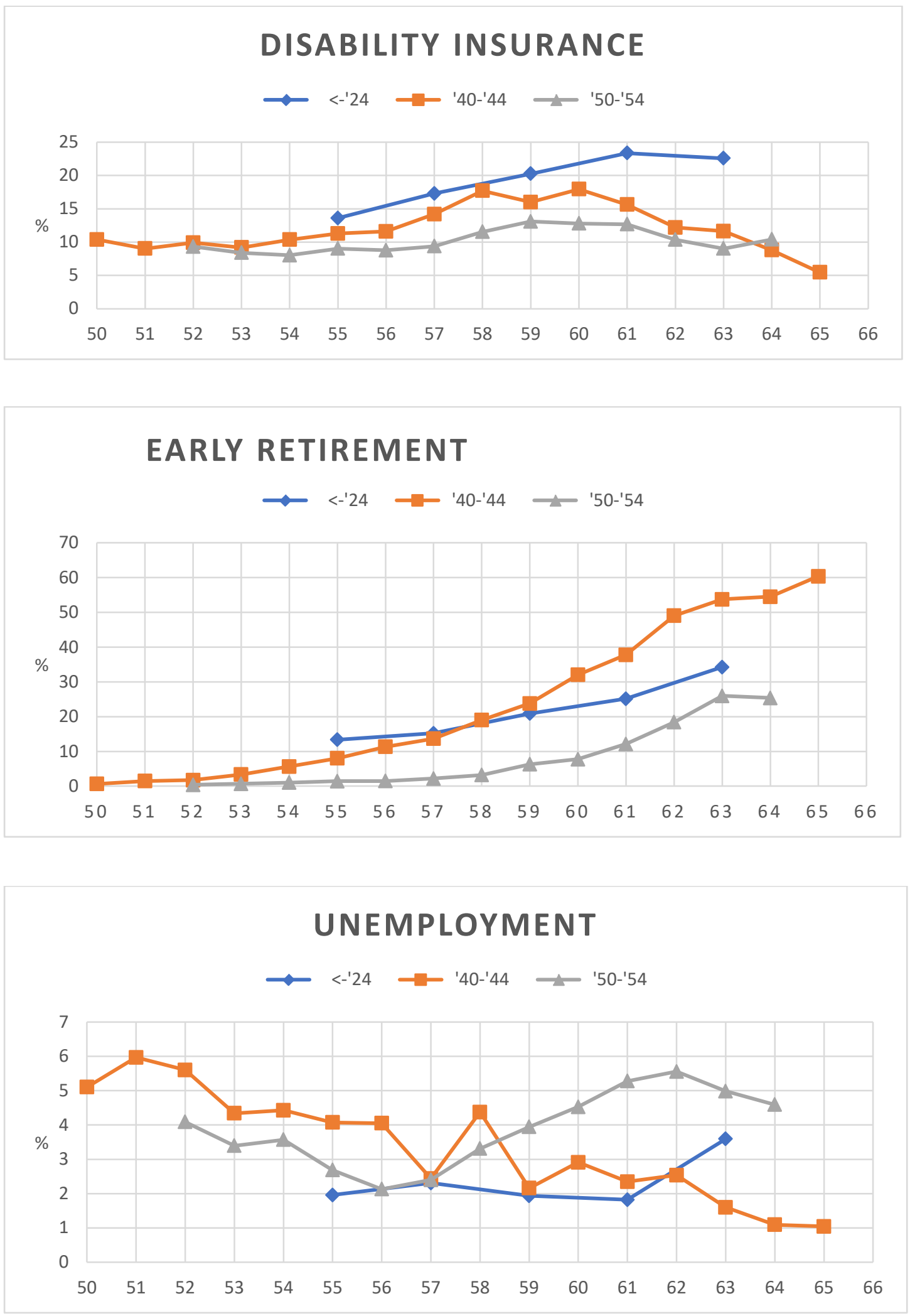

Note: The unemployment rate includes individuals on unemployment insurance and social assistance. Source: Statistics Netherlands, Labor Force Survey (Enqûete Beroepsbevolking; EBB). 


\subsection{The effect of an increase in the State Pension Age (SPA) on employment}

In the Netherlands, employment contracts are terminated by law when workers reach SPA and state pensions are automatically received. This does not prevent employees and employers to enter into a new employment contract, but it does mean that employment can be terminated without the need of severance pay. It may also be interpreted as a signal that this is the right age to stop working. Thus, SPA may be a barrier for working longer. To obtain insights into this we exploit recent increases in SPA and examine the impact of this on working longer. Table 2 and Figure 11 present the SPA reforms: a gradual increase by one or three months depending on the year and month of birth and effective in the calendar year individuals reach their SPA age.

Table 2. The state pension age by age and calendar year

\begin{tabular}{|c|c|c|c|c|c|}
\hline \multirow{2}{*}{$\begin{array}{l}\text { Age in } \\
\text { years \& } \\
\text { months }\end{array}$} & \multicolumn{5}{|c|}{ Receives a state pension (yes/no) } \\
\hline & $<=2012$ & 2013 & 2014 & 2015 & 2016 \\
\hline $64 y+11 m$ & no & no & no & no & no \\
\hline $65 y$ & yes & no & no & no & no \\
\hline $65 y+1 m$ & yes & yes & no & no & no \\
\hline $65 y+2 m$ & yes & yes & yes & no & no \\
\hline $65 y+3 m$ & yes & yes & yes & yes & no \\
\hline $65 y+4 m$ & yes & yes & yes & yes & no \\
\hline $65 y+5 m$ & yes & yes & yes & yes & no \\
\hline $65 y+6 m$ & yes & yes & yes & yes & yes \\
\hline $65 y+7 m$ & yes & yes & yes & yes & yes \\
\hline
\end{tabular}




\section{Figure 11 State Pension Age (SPA) by calendar year.}

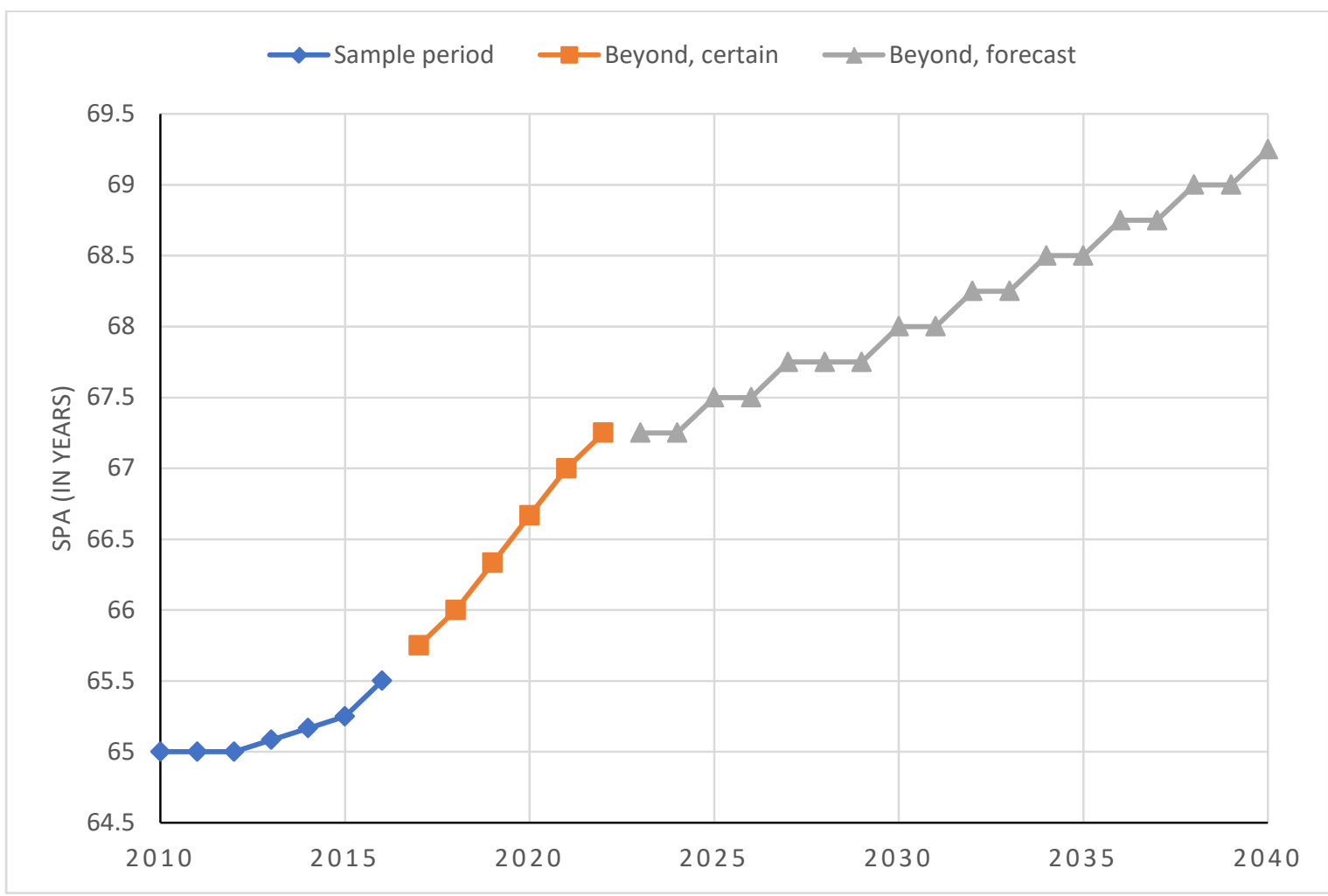

Note : From the introduction of SP in 1957 until and including 2012, SPA was equal to 65.

Source: http://wetten.overheid.nl/BWBR0002221/2017-01-01

We analyze the impact of SPA on men's employment rates around the age of 65 using a difference-in-difference methodology (Angrist and Pischke 2009). Figures 12 and 13 are based on regression results and show predicted employment rates by age and year. That is, the years signify the reforms listed in Table 1 . Figure 12 shows the impact of an SPA increase from age 65 to age 65 plus one month; an increase that occurred between 2012 and 2013. As this figure shows, the employment rate of individuals aged 65 plus one month who are affected by this reform increases to the level for individuals who are 64 years plus 11 months of age. This increase is statistically significant at the $1 \%$ level. That is, almost all of them remain employed at the age of 65 plus one month. Individuals aged 65 plus 7 months are not 
affected by the SP reforms during these years. That is, during those years, employment rates at 64 plus 11 months and 65 plus 7 months serve as upper and lower bounds, respectively.

Next, Figure 13 shows the employment rates related to all the step-wise increases in SPA until 2016. This Figure shows that a one month increase in SPA leads to workers, on average, working one month longer. This is shows up in Figures 12 and 13 as approximately 10 percentage point increases in the employment rate (the "jumps”). This increase is statistically significant at the one percent level.

Figure 12 Predicted men's employment rate at three selected ages by calendar year

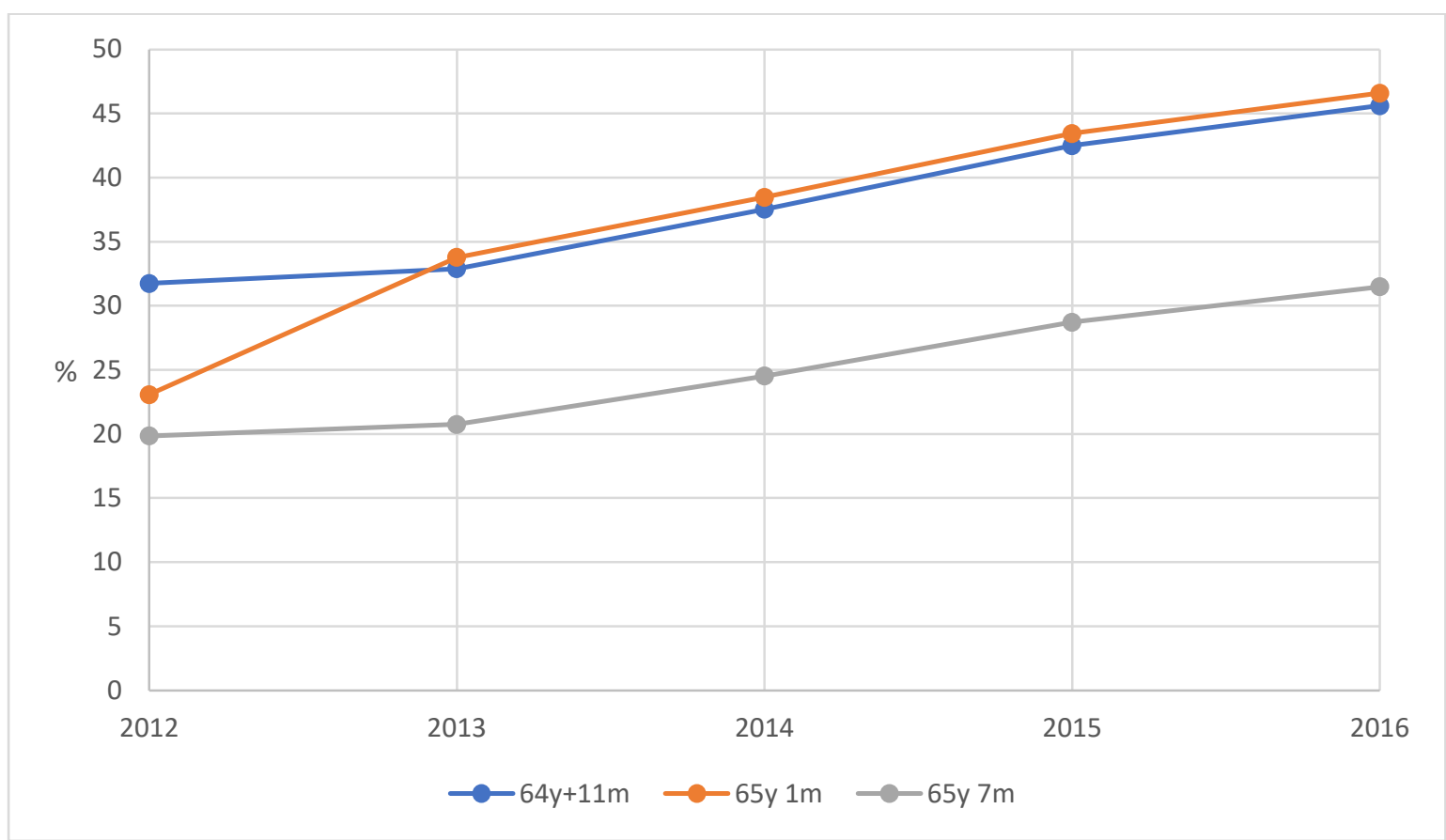

Source: own calculations using the Labor Force Survey, Statistics Netherlands (Enqûete Beroepsbevolking; EBB). 
Figure 13 Predicted men's employment rate at different ages by calendar year

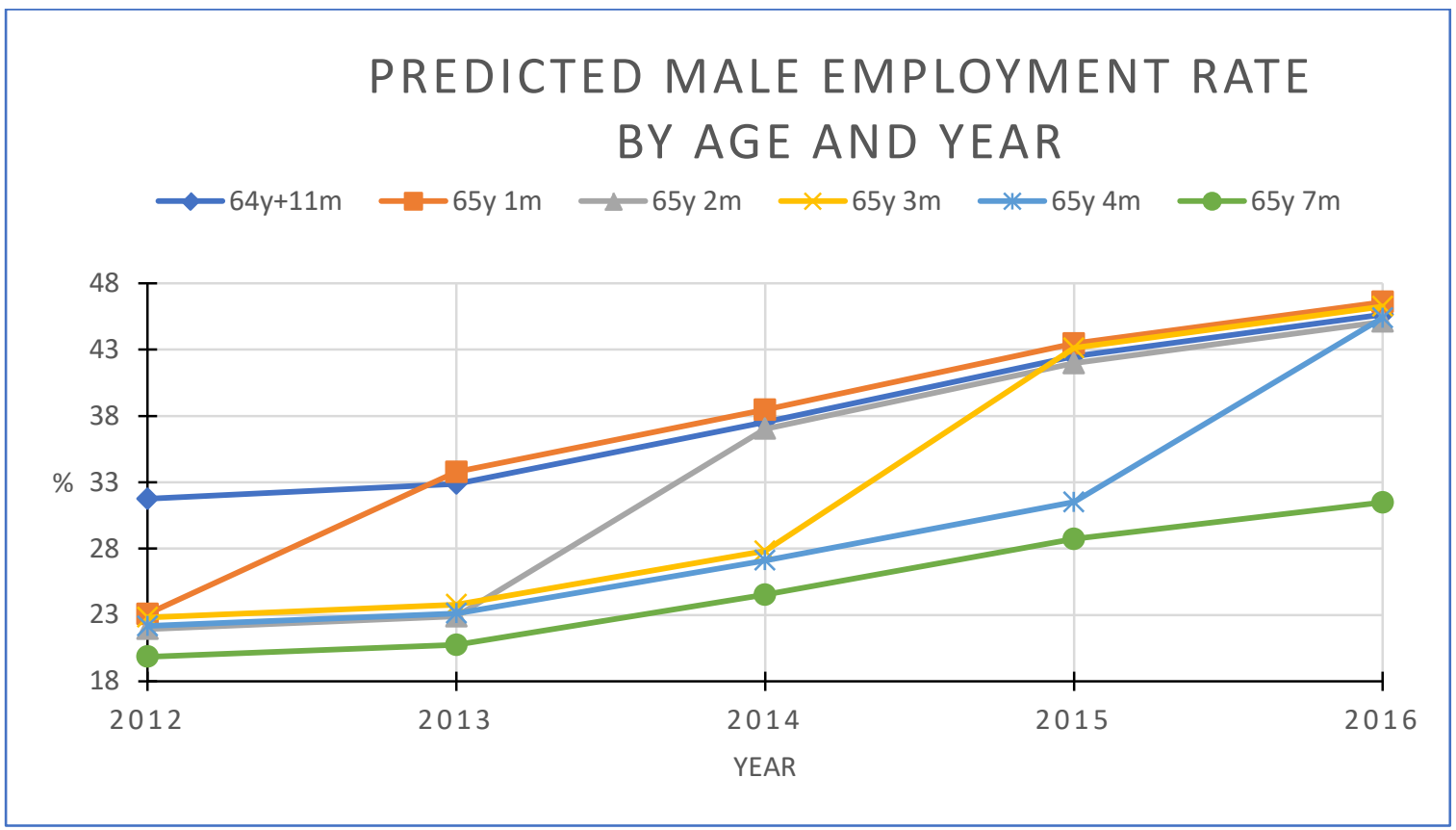

Source: own calculations using the Labor Force Survey, Statistics Netherlands (Enqûete Beroepsbevolking; EBB).

\section{Conclusions}

The findings of this chapter show the importance of incentives provided by social security programs for the pathways to retirement and working longer. Implicit tax rates on working are a measure of the financial incentives to exit the labor force. The implicit tax rates show for the various pathways that (i) DI remains an attractive option (if eligible), (ii) UI has been an attractive option for older workers (if eligible) until 2004 after which the scheme became less generous, and, (iii) early retirement remained an attractive option until 2006, after which ER pensions became close to being actuarially fair. Regarding state pensions, the SPA has since 2013 step-wise been increased but the benefits remained unchanged.

Given eligibility for DI, UI and/or ER/SP, retiring considerably earlier than the State Pension Age (65 until 2013) used to be a financially attractive decision, at least between 1987 and 2004. UI and ER have become less attractive options, and nowadays the financial incentives 
for these schemes no longer encourage early retirement. For persons eligible for DI the financial incentive to retire has hardly changed but here eligibility appears to have been successfully reduced by the most recent reform in 2006. Generally, the Netherlands has seen a vast number of reforms, which makes empirically assessing the effect of each individual reform difficult. Nevertheless, the combined reforms of SSPs seem to have had large positive effects on employment at older ages.

We have shown, using the step-wise increase in SPA from 2013 onwards, that an increase in SPA leads to working longer. Whilst this effect is strong, we cannot identify the mechanisms that play a role in this relationship. As noted before, employment protection terminates at SPA, so at least one mechanism is that employers can initiate severance without facing severance costs. On the other hand, workers could still exit at age 65 if they wanted to. It appears however that generally this does not happen. This may indicate a preference for working longer, or adoption of a shifting social norm whereby one is expected to keep working until SPA. A third factor is that state pensions are received from SPA onwards. Liquidity constrained workers may therefore prefer to keep working until their income is supplemented with SP. Identifying the relative roles of the various mechanisms is of importance for evaluating the welfare implications of an increase in SPA. Nevertheless, it is likely that the continuing increase in SPA will further increase employment at older ages. 


\section{References}

Angrist, Joshua D. and Jörn-Steffen Pischke, 2009. Mostly harmless econometrics, Princeton University Press, New Jersey.

Kalwij, Adriaan, Alessie, Rob, Gardner, Jonathan, and Ashik Anwar Ali, 2018, Inflation experiences of retirees, Journal of Pension Economics and Finance, 17(1): 85-109.

Kalwij, Adriaan, Kapteyn, Arie, and Klaas de Vos, 2017. Why are People Working Longer in the Netherlands?, mimeo.

Kapteyn, Arie, and Klaas de Vos, 1999. Social Security and Retirement in the Netherlands”, in: Jonathan Gruber and David A. Wise (eds.), Social Security and Retirement around the World, The University of Chicago Press, 269-304. 
Appendix: Key parameters of retirement pathways for selected years.

\begin{tabular}{|c|c|c|c|c|c|c|c|c|c|}
\hline$E E A$ & $\mathrm{DI}$ & $\mathrm{UI}$ & & ER & Earnings tests & $\mathrm{DI}$ & UI & $\mathrm{SP}$ & ER \\
\hline 1980 & - & - & 65 & $60-62$ & 1980 & $*$ & $*$ & none & 0 \\
\hline 1985 & - & -; 57.5 & 65 & $60-62$ & 1985 & $*$ & $*$ & none & 0 \\
\hline 1990 & - & ; 57.5 & 65 & $60-62$ & 1990 & $*$ & $*$ & $* *$ & 0 \\
\hline 1995 & - & $-; 57.5$ & 65 & $60-62$ & 1995 & $*$ & * & $* *$ & 0 \\
\hline 2000 & - & ; 57.5 & 65 & $60-62$ & 2000 & * & * & $* *$ & 0 \\
\hline 2005 & - & ; 57.5 & 65 & $60-62$ & 2005 & $*$ & $*$ & $* *$ & 0 \\
\hline 2010 & - & $-; 61.83$ & 65 & $60-62$ & 2010 & $*$ & $*$ & $* *$ & none \\
\hline 2015 & - & $-; 62.08$ & 65.25 & & 2015 & $*$ & $*$ & $* *$ & none \\
\hline \multicolumn{5}{|c|}{ DI: no EEA, unlimited duration until 65} & \multicolumn{5}{|c|}{ * benefit depends on earnings } \\
\hline \multicolumn{5}{|c|}{$\begin{array}{l}\text { UI: no EEA, 1984-2006 unlimited duration from age } 57.5 \\
\text { until age } 65\end{array}$} & \multicolumn{5}{|c|}{$* *$ supplement depends on earnings spouse $<65$} \\
\hline \multicolumn{5}{|c|}{ ER: EEA depends on sector/firm } & \multicolumn{5}{|c|}{$\begin{array}{l}\text { none: benefit does not differ with earnings } \\
0: \text { usually no benefit if earnings }>0 \text { (working not } \\
\text { allowed) }\end{array}$} \\
\hline \multicolumn{5}{|c|}{ Required service years } & \multicolumn{5}{|c|}{ Other eligibility requirements } \\
\hline & DI & $\mathrm{UI}$ & SP & ER & & $\mathrm{DI}$ & UI & SP & ER \\
\hline 1980 & $>0$ & $*$ & $* *$ & usually: 10 & 1980 & $*$ & $* *$ & none & none \\
\hline 1985 & $>0$ & $*$ & $* *$ & usually: 10 & 1985 & * & $* *$ & none & none \\
\hline 1990 & $>0$ & * & $* *$ & usually: 10 & 1990 & $*$ & $* *$ & none & none \\
\hline 1995 & $>0$ & $*$ & $* *$ & usually: 10 & 1995 & * & $* *$ & none & none \\
\hline 2000 & $>0$ & $*$ & $* *$ & usually: 10 & 2000 & $*$ & $* *$ & none & none \\
\hline 2005 & $>0$ & $*$ & $* *$ & usually: 10 & 2005 & $*$ & $* *$ & none & none \\
\hline 2010 & $>0$ & $*$ & $* *$ & $* * *$ & 2010 & * & $* *$ & none & none \\
\hline 2015 & $>0$ & * & $* *$ & $* * *$ & 2015 & $*$ & $* *$ & none & none \\
\hline \multicolumn{5}{|c|}{ * duration depends on service years } & \multirow{3}{*}{\multicolumn{5}{|c|}{$\begin{array}{l}*: \text { deemed disabled for work, criteria have shifted } \\
* *: \text { unemployed and looking for work (1984 } \\
-2006) \text { : from age } 57.5 \text { job no search needed) }\end{array}$}} \\
\hline$* *$ benefit & deper & $\mathrm{n}$ years of & sidence 15 & $5-65$ & & & & & \\
\hline$* * *$ flexibl & $E R / P$ & pends on & ars of serv & & & & & & \\
\hline \multicolumn{5}{|c|}{ Actuarial adjustments } & \multicolumn{5}{|c|}{ Replacement rates } \\
\hline & $\mathrm{DI}$ & $\mathrm{UI}$ & SP & ER & & $\mathrm{DI}$ & $\mathrm{UI}$ & $\mathrm{SP}+\mathrm{PP}$ & ER \\
\hline 1980 & no & no & no & no & 1980 & 80 & $80 / 75$ & $<=70$ & 80 \\
\hline 1985 & no & no & no & no & 1985 & 70 & 70 & $<=70$ & 80 \\
\hline 1990 & no & no & no & no & 1990 & 70 & 70 & $<=70$ & 80 \\
\hline 1995 & no & no & no & no & 1995 & 70 & 70 & $<=70$ & 80 \\
\hline 2000 & no & no & no & no & 2000 & 70 & 70 & $<=70$ & 80 \\
\hline 2005 & no & no & no & yes & 2005 & 70 & 70 & $<=70$ & 80 \\
\hline 2010 & no & no & no & yes & 2010 & 75 & $75 / 70$ & $<=70$ & 70 \\
\hline 2015 & no & no & no & yes & 2015 & 75 & $75 / 70$ & $<=70$ & 70 \\
\hline
\end{tabular}




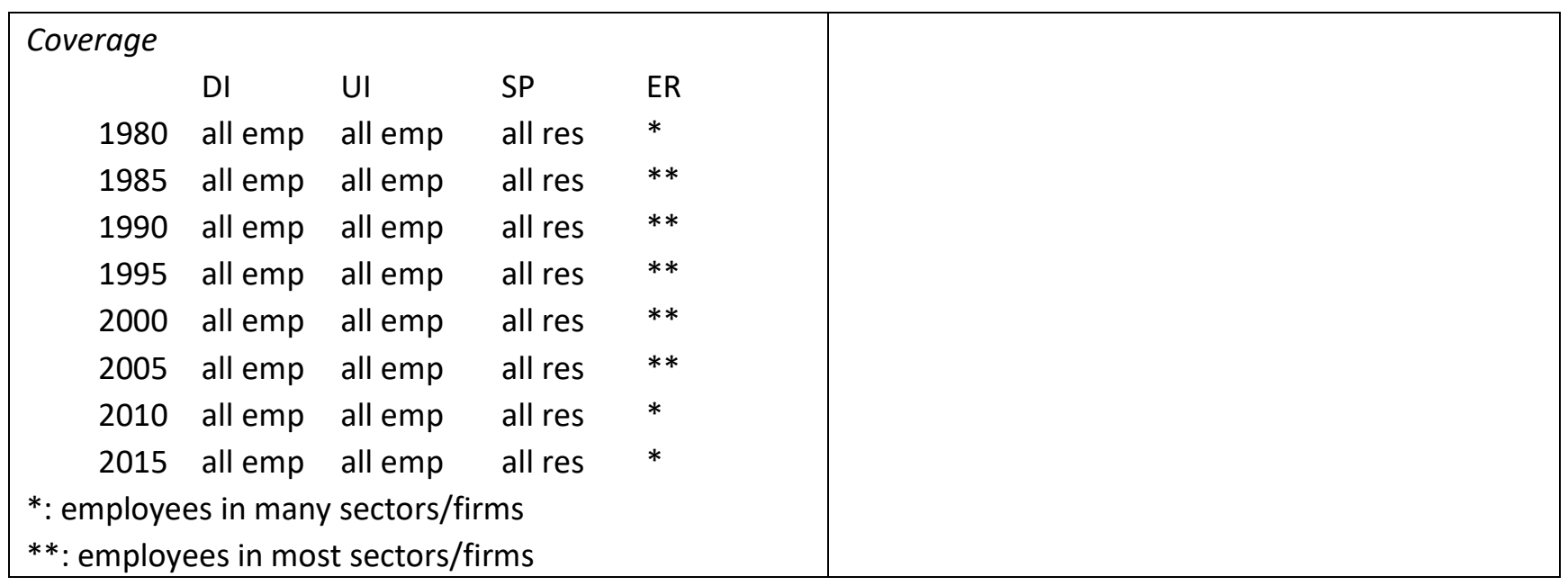

